Lucia M. S. Galli, The Accidental Pilgrimage of a Rich Beggar. The Account of tshong dpon Kha stag 'Dzam yag's Travels through Tibet, Nepal, and India (1944-1956)

\title{
OpenEdition
}

Electronic version

URL: https://journals.openedition.org/emscat/2961

DOI: 10.4000/emscat.2961

ISSN: 2101-0013

Publisher

Centre d'Etudes Mongoles \& Sibériennes / École Pratique des Hautes Études

Electronic reference

"Lucia M. S. Galli, The Accidental Pilgrimage of a Rich Beggar. The Account of tshong dpon Kha stag 'Dzam yag's Travels through Tibet, Nepal, and India (1944-1956)", Études mongoles et sibériennes, centrasiatiques et tibétaines [Online], 48 | 2017, Online since 05 December 2017, connection on 13 July 2021. URL: http://journals.openedition.org/emscat/2961 ; DOI: https://doi.org/10.4000/emscat.2961

This text was automatically generated on 13 July 2021

(C) Tous droits réservés 


\section{Lucia M. S. Galli, The Accidental Pilgrimage of a Rich Beggar. The Account of tshong dpon Kha stag 'Dzam yag's Travels through Tibet, Nepal, and India (1944-1956)}

\section{REFERENCES}

D.Phil thesis, defended on $12^{\text {th }}$ June 2017 at the University of Oxford. Committee:

C. Ramble (examiner), F.-X. Erhard (examiner), U. Roesler (supervisor)

I am the one known by the affectionate name of 'Dzam yag and the dharma name of Ngag dbang dar rgyas, the one continuously disturbed by mental afflictions. I was born at the centre of the region called Rab shis, considered to be a part of the sGa [district of Yushu], Khams. Up to the age of forty-nine, I went through success and failure, happiness and sadness, sometimes with and sometimes without the disposition and capacities [to dedicate myself] to the dharma; had I to write all [the things that happened to me] it would be [endless] like ripples of water. As for [these events], some raise compassion, some inspire renunciation, some fall into the [category] of wrongdoings, and others are humorous, but, since there are too many of them, they will not be the focus of my writing. When I was forty-nine, due to a series of circumstances, I wandered through the three provinces of Tibet, alone, without a lord [to protect me], relying on [the support of my] co-regionals; I shall therefore write a little about my circumambulations and the visits [I paid] to extraordinary places and the Three Supports [symbols of the Buddha's body, speech, and mind], so as to keep [them] in my mind.

1 The passage above is the only biographical information Kha stag 'Dzam yag, a Khams pa trader and author of the text at the core of my dissertation, provides about the years preceding the events that led to the compilation of his journal. In this extremely abridged version of the first forty-eight years of his life, the author provides crucial details about himself - elements that deeply contributed to my understanding of his 
figure; throughout the writing of this thesis, I kept going back to these lines, until they became the key to my interpretation of 'Dzam yag's personality.

In his seminal essay, Georges Gusdorf boldly claims that "the genre of autobiography seems limited in time and in space: it has not always existed nor does it exist everywhere [...] One would say that it expresses a concern peculiar to Western man [...] the concern, which seems so natural to us, to turn back on one's own past, to recollect one's life in order to narrate it [...]" (Gusdorf 1980: pp. 28-29), a statement the veracity of which had already been questioned by Janet Gyatso (Gyatso 1998: pp. 101-102); as is well-known, the Tibetan literary canon presents a wide array of life writing, including the autobiographical type, of which 'Dzam yag's journal (Tib.nyin deb) is but one example. Although not an autobiography in the strict sense, the text is an autodiegetic narration of past events, retrospectively recollected in a diary format. The author himself identifies the desire to preserve the memory of past events as the main motivation for his writing, in blunt defiance of Gusdorf's assertion.

As for any autobiographical narrative with claims to factuality, the distinction in the journal between factual and fictional is somewhat unclear; the retrospective process of narratisation of facts, together with the reconstruction of the past in the light of the present, allows for fictional elements to partially infringe on the outspoken authorial declaration of factuality, without nonetheless compromising the inherent truth of the facts themselves. Modern literary scholars have recognised the profoundly hybrid status of life writing - suspended as it is between the poles of fact and fiction, a feature confirmed by the journal as well.

4 In the course of my dissertation, I used two different heuristic devices, i.e. narratology and socio-economic analysis, in an attempt to capture the multi-layered and complex essence of 'Dzam yag's journal. Whereas from a literary point of view, the journal is a peculiar form of autodiegetic writing, structured as a journal/ledger, and prone, as any autobiographical text, to reflect the idiosyncratic tendencies of the author, the factual features at its core make it a valuable source of historical information on mid- $20^{\text {th }}$ century Tibet, and, as such, worthy of being analysed from a socio-economic perspective.

5 Regardless of the actual level of literacy in pre-modern Tibet, an author's social persona could rarely escape the influence of the ideal concepts of personhood transmitted and made culturally acceptable by the textual tradition. The popularity enjoyed by indigenous biographical and hagiographical writings of charismatic individuals ensured the social acceptance of specific kinds of behaviour, which were actively replicated and adapted in daily life. In the case of the journal, intertextuality appears to take place in different locations, i.e. in the work and in the author. Not only are references to different texts present throughout the journal, but 'Dzam yag himself actively interacts with textual utterances, an experience that thus becomes inherent to the journal itself. Intertextuality raises valid questions about the cognitive and social dimension of textual exposure, interaction, and interpretation in pre-modern Tibet; in the context of the present discussion, the role played by the figure of Mi la ras pa as an ideal concept of personhood is crucial to the development of 'Dzam yag's selfperception and its evolution from a past "narrated self" to a present "narrating self".

6 The use of narratology as a heuristic device allows identifying the interplay of memory, self, and culture in the socio-historical context of mid- $20^{\text {th }}$ century Tibet. The journal is the narration of a journey that is both spiritual and physical - the evolution of its 
author's inner self matching his outer activities, whether they be ritual pilgrimages or trade ventures. The latter represent the factual element around which the journal is structured; by reflecting on the journal as a form of social history, distinct from its literary manifestation as autobiographical narrative, I will isolate socio-economic and cultural factors linked to the development of a strong and influential trading class, mainly composed of eastern Tibetan families, and the political weight the latter came to assume in $20^{\text {th }}$ century Tibet. Moreover, the information contained in 'Dzam yag's journal offers precious insights into the development of new pilgrimage rituals and routes to the holy sites of India and the emergence of what could be understood as a proto-form of "spiritual tourism".

7 The journal is more than a personal story; it is social history as well, as it demonstrates the power of a person's cultural background and the impact of external events in shaping the author's life. The autobiographical narrative of the journal, viewed in its socio-cultural context reveals the economic, political, and religious interactions influencing the self-representation of the author. Social history has much to learn from personal narratives, for they provide a glimpse of both the nexus of individual lives and the larger socio-cultural context in which those lives are lived. In the journal, the connection to Khams in general and with the author's ancestral land (Tib. pha yul) in particular is essential for understanding the way the world is perceived and described. Kha stag 'Dzam yag is first and foremost a Khams pa; in the thirteen-year period covered in his journal, he travelled extensively inside and outside the plateau, relying on the support of local Khams pa enclaves, communities created in large cities and trade hubs to facilitate the interaction between fellow countrymen and the surrounding foreign environment.

\section{Synopsis of Chapters}

The thesis consists of four chapters, each subdivided into sections and subsections. Generally speaking, the journal will be presented and analysed from a socio-economic perspective blended with a narratological approach.

Chapter One introduces the journal from a literary point of view. The first three sections of the chapter discuss the complexities inherent in a taxonomic classification of Tibetan literature in general and the correct categorisation of the journal in particular, by proposing the adoption of a prototype theory for the identification of the "genre" of travel literature. In presenting 'Dzam yag's text as a narrative autodiegetic product, the last section of Chapter One investigates the hybrid character of the work by questioning its inclusion in the diaristic genre. The chapter ends with a discussion of the autobiographical elements contained in the journal, thus highlighting both the socio-historical context and the influence the cultural and traditional Tibetan milieu exercises on the way the narrator perceives himself and the world surrounding him. The aim of Chapter One is therefore to place the author and his sensibility at the forefront, allowing the scholar to better understand the figure through whom the events and facts narrated in the journal have been filtered.

In Chapter Two and Chapter Three a socio-economic perspective is used to investigate the claims to factuality made by the author.

Chapter Two opens with a broad historical overview of the political, cultural, and social developments undergone by the kingdom of Nang chen - an eastern Tibetan polity of 
which 'Dzam yag's ancestral land was a territorial division - from the $13^{\text {th }}$ to the $20^{\text {th }}$ centuries. This realm, largely inhabited by nomadic and seminomadic communities, has been almost ignored by Western scholarship, with the sole exception of Maria M. Turek, who has worked extensively on the local hermitic tradition and its revival in times of political and social change. In Chapter Two I will provide a detailed genealogy of the royal lineage of the 'Bru Tre bo, a local clan which ruled the kingdom from the late $13^{\text {th }}$ century up to the Communist invasion in the 1950s. The chronological reconstruction of the lineage - being of historical value per se, due to the understudied status of Nang chen - allows a retracing of the emergence of a nonsectarian (Tib. ris med) approach within the royal court of Nang chen since the mid-19 $9^{\text {th }}$ century, as well as its diffusion at a local level. Ris med values transpire from the narrative of the journal, and no full understanding of the author's personality can be obtained without considering his upbringing in a cultural environment imbued with reformist and revivalist non-sectarian ideals. The second and third sections of Chapter Two focus on Kha stag 'Dzam yag's ancestral land and the events that led to the composition of his journal. In the fourth and last section of the chapter, questions are raised concerning the real factors that motivated the author's wanderings, and whether they may be correctly considered as "pilgrimages", as he himself suggests.

Chapter Three focuses on trade, corroborating the historical knowledge of pre-modern Tibetan economy by the data taken from the journal narrative. Particular attention will be paid to the role that the Khams pa trading communities played in the Tibetan political arena in the 1940s and 1950s. The chapter also advances some hypotheses on the economic influence of the ris med movement as a trade facilitator, as well as on a possible affiliation of 'Dzam yag with the influential Sa 'du tshang family, for whom the author appears to have worked as trade agent and thanks to whom he managed to obtain a commission from the Khang gsar bla brang ${ }^{1}$ of the Ngor E wam chos ldan monastery. By trading for one of the colleges of the Sa skya establishment, he de facto gained the title reserved for monastic trade agents, i.e. "chief merchant" (tshong dpon). In following some of 'Dzam yag's business ventures to Kalimpong, the chapter briefly dwells on the idiosyncratic character of the Sikkimese trade hub, by the mid- $20^{\text {th }}$ century one of the most active centres for the sorting and processing of Tibetan wool, a commodity over which the three largest firms of Tibet -sPang mda' tshang, Sa 'du tshang, and Rwa sgreng - held monopoly. In the late 1940s and throughout the 1950s, Kalimpong was a safe harbour for Tibetans of all sorts - pilgrims, traders, and several figures declared persone non grate by the Tibetan government, i.e. the dGa' ldan pho brang.

13 Chapter Four deals extensively with pilgrimage and ritual activities - which clearly represent the core of 'Dzam yag's narrative - and it does so by merging an economic and a literary approach. The previous chapters, by analysing the political and socioeconomic situation of pre-1959 Tibet, provide the necessary background for the appraisal of the information of which the journal is a unique source. In broaching the topic of pilgrimage, it is impossible not to engage in a literary analysis of the journal, for any textual utterance is not created in a vacuum, but is inscribed in webs of cultural, social, political, and literary significance; to understand a text means therefore to be aware of the social conceptions and cultural codes inherent to the context it is produced in. Whereas the socio-economic approach allows discussing religion as an independent variable vis-à-vis economy, the understanding of the journal as a narrative text connected to others sheds light on the sense-making and sense- 
giving processes at work during a pilgrimage to sacred places. The chapter is divided into two sections which differ in their approach as well as their focus; the locus of investigation will shift from the Tibetan Plateau - examined in the first section - to the "holy lands" of India and Nepal - which are the background for the analysis carried out in the second section.

In the first section, the ritual activities and pilgrimage routes, as recorded in the journal, are interpreted in the light of their socio-economic importance; the aim is to identify the power wielded by religious communities, by taking into consideration the amount of money generated by pilgrimages and the different intentions and expectations driving the devotees.

In the second section, narratology is used as the leading heuristic device. The author's impressions of India and its modernity offer a glimpse of the development of new kinds of pilgrimage rituals, as well as on the emergence of a form of spiritual tourism; exoticism enters the narrative, turning the journal/ledger into a real travelogue.

The Conclusion connects the socio-economic and the narratological approach, identifying the major topics discussed in the previous chapters and providing some final observations on the figure of Kha stag 'Dzam yag and the value of his journal as a historical source.

\section{BIBLIOGRAPHY}

Gusdorf, G. 1980 Conditions and Limits of Autobiography, in J. Olney, Autobiography. Essay Theoretical and Critical (Princeton, Princeton University Press), pp. 28-47.

Gyatso, J. 1998 Apparitions of the Self: the Secret Autobiographies of a Tibetan Visionary. A Translation and Study of Jigme Lingpa's Dancing Moon in the Water and Dākki's Grand Secret-talk (Princeton, Princeton University Press).

\section{NOTES}

1. The term blabrang is used to indicate the institutional residence of an abbot, as well as monastic corporate estate belonging to a lineage of incarnate lamas. 